\title{
Infection status of Clinostomum complanatum (Rudolphi, 1819) metacercaria from Channa punctatus of M eerut District
}

\author{
Bindu Sharma*, Vidushi R ani and Ayushi Chaudhary \\ Department of Zoology, D.N.P.G. College, Meerut (U.P.), INDIA \\ *Corresponding author. E-mail: bindu2502@ rediffmail.com
}

\begin{abstract}
Metacercaria Clinostomum complanatum is a digenetic trematode, which is mainly found in fresh water fishes. Present communication deals with the infection status of $C$. complanatum in $C$. punctatus of Meerut district, which is supported by the data spreading over one year. About 250 specimens of $C$. punctatus from different ponds of Meerut were studied through regular periodical collection in the year Jan 2010 to Dec 2010. Overall prevalence $35.6 \%$, mean intensity 3.06 and abundance 1.09 were reported. The infection was maximum in winter and minimum in rainy season. Prevalence, intensity and abundance of the infestation were also found to be related to different length group and sex of the hosts, the medium sized fishes were more infected and the larger size fishes were less infected while the smaller size fishes showed moderate infection. Susceptibility of infection was not significantly different between male and female fish.
\end{abstract}

Keywords: Clinostomum complanatum, Freshwater fish, Channa punctatus

\section{INTRODUCTION}

Family Clinostomatidae has a widespread distribution. C. complanatum (Rudolphi, 1819) is a digenetic trematode which causes yellow grub in the muscle of fish and makes them unsuitable for human consumption. At many occasions human infection has also been recorded (Chung et al., 1995; Isobe et al., 1994; Kifune et al., 2000). Many species of fresh water fishes were recorded as the second intermediate host of C. complanatum (Yamaguti, 1933; Aohagi et al., 1992a and 1993). In Indian subcontinent presence of this larval digenea has been noticed at several places. C. complanatum metacercariae infect the skin, muscle, fins, head and viscera, causing pathologies and changes in the host behavior, with consequent economic losses in fish farms (Kagei et al., 1984; Eiras, 1994; Mitchell, 1995). The infection of Clinostomum also depends on the host size (Kalantan et al., 1987). The present study was aimed to consider the seasonal variation with respect to prevalence, mean intensity and abundance of $\mathrm{C}$. complanatum with regard to sex and length groups of the fish $C$. punctatus.

\section{MATERIALS AND METHODS}

Fishes were bought live to the laboratory throughout the year from different water bodies of Meerut district viz: village Kohalla, village Ikri, village Kakkapur, village Sururpur, village Durjanpur, Ramtal Vatika, Hastinapur, Daulatpur, Baadam, Daha, Mehrawati and Qilla Parikshitgarh, examined within $24 \mathrm{hr}$ of capture. The standard length of each fish was measured and their sex was determined. Fish were examined for the presence of external metacercaria then dissected and studied for internal metacercaria but no external metacercaria was found. The location of internal metacercaria and their number was recorded. Collected specimens were washed and preserved in $70 \%$ alcohol, after flattening under a moderate pressure using a cover glass slide. Fixed specimens were stained with aceto carmine, dehydrated, cleared and mounted in Canada balsam.

Prevalence, mean intensity and abundance concepts as suggested by Margolis et al. (1982) are used in present study.

Prevalence $\%-\frac{\text { Total no. of host infected }}{\text { Total no. of host examined }}$ X 100
Mean Intensity $-\frac{\text { Total no. of parasite }}{\text { Total no. of host infected }}$
Abundance $-\frac{\text { Total no. of parasites }}{\text { Total no. of host examined }}$

\section{RESULTS}

A total of 250 C.punctatus were sampled throughout the year from January 2010 to December 2010. The infection status of $C$. complanatum was studied throughout the year. During the course of entire study, 89 fishes were infected out of 250.273 C.complanatum were collected from the body cavity and muscles and tissues around the gills of C. punctatus. 174 parasites were recovered 
Table 1. Monthly variation in prevalence \%, mean intensity and abundance of C.complanatum in C. punctatus during the year 2010.

\begin{tabular}{lcccccc}
\hline M onth & $\begin{array}{c}\text { No. of host } \\
\text { examined }\end{array}$ & $\begin{array}{c}\text { No. of host } \\
\text { infected }\end{array}$ & Prevalence $\%$ & $\begin{array}{c}\text { No. of } \\
\text { parasites }\end{array}$ & $\begin{array}{c}\text { M ean intensity } \\
\text { ratio }\end{array}$ & $\begin{array}{c}\text { A bundance } \\
\text { ratio }\end{array}$ \\
\hline January & 15 & 05 & 33.3 & 17 & 3.40 & 1.13 \\
February & 15 & 04 & 26.6 & 09 & 2.25 & 0.60 \\
March & 18 & 06 & 33.3 & 13 & 2.16 & 0.72 \\
April & 25 & 08 & 32.0 & 17 & 2.12 & 0.68 \\
May & 24 & 08 & 33.3 & 20 & 2.50 & 0.83 \\
June & 21 & 6 & 28.5 & 14 & 2.33 & 0.66 \\
July & 22 & 05 & 22.7 & 11 & 2.20 & 0.50 \\
August & 20 & 04 & 20.0 & 08 & 2.0 & 0.40 \\
September & 15 & 04 & 26.6 & 09 & 2.25 & 0.60 \\
October & 20 & 06 & 30.0 & 12 & 2.0 & 0.60 \\
November & 25 & 16 & 64.0 & 82 & 5.12 & 3.28 \\
December & 30 & 17 & 56.6 & 61 & 3.58 & 2.03 \\
\hline Total & 250 & 89 & 35.6 & 273 & 3.06 & 1.09 \\
\hline
\end{tabular}

from the body cavity and 99 from the muscles and tissues around the gills. During this study highest prevalence were observed in Nov (64.0\%) and Dec (56.6\%) and lowest were observed in July (22.7\%) and Aug (20.0\%), maximum mean intensity (5.12) was recorded in Nov and minimum (2.0) in Aug and Oct, highest abundance (3.28) was noticed in Nov and lowest in Aug (0.40) (Table.1).

On the basis of length group highest prevalence $(50.0 \%)$ were recorded from medium length group $(10-12 \mathrm{~cm})$ and lowest $(20.0 \%$ ) from larger length group (Above $16 \mathrm{~cm}$ ), highest mean intensity (4.26) was observed in smaller length group (Less than $10 \mathrm{~cm}$ ) and lowest mean intensity (2.50) in larger length group (Above $16 \mathrm{~cm}$ ), highest abundance (1.34) were recorded from medium length group (10-12 cm) and lowest abundance (0.50) in larger length group (Above $16 \mathrm{~cm}$ ) (Table.2). Infection (in female fishes $37.9 \%$, in male fishes $33.3 \%$ ) and abundance (in female 1.32 , in male fishes 0.86 ) was comparatively more in female fishes than male fishes respectively, but differences are not significant. (Table 3).

\section{DISCUSSION}

The prevalence, mean intensity and abundance of parasite as recorded from monthly observation were maximum in the month of November-December (winter season) and the minimum in the month of July-August (Rainy season). According to Sithithaworn and Haswell-Elkins (2003) fish have their highest metacercarial burden in winter because snail population and fluke transmission are low during earlier winter dry season, and with the resumption of rain and high temperature, snail population increase, and fluke eggs shed into the environment are more likely to be washed into water bodies (Long-Qi et al., 2004). The events lead to increasing snail infection and cercarial production, which result in the accumulation of fish metacercariae at about the time the rainy season ends in the late fall and winter (approximately Nov-Dec). The fall in water temperature during cooler months reduces the immune response in fish and makes them more vulnerable to disease vectors Akhter et al. (1977) and Banu et al. (1993) also reported more incidence of diseases in fish during winter months.

The prevalence of infection of the parasites in relation to size showed that the larger the fish the lower the infestation, possibly due to development of immunity against it. It was found that fish above the length of 16 $\mathrm{cm}$ had lowest parasitic infection while those having the length of 10-12 cm had the highest level of infection. This agrees with the work of Malek and Mobedi (2001). It was observed that among the different size groups of fishes, the maximum infestation were recorded from the medium length group than the smaller and larger length group of fishes. The rate of infestation was more in smaller length group than larger, but prevalence of infestation in the medium group was more than smaller group (Golder et al., 1987).

Table 2. Prevalence, mean intensity and abundance of $\mathrm{C}$.complanatum in different length groups of $\mathrm{C}$. punctatus.

\begin{tabular}{lcccccc}
\hline $\begin{array}{l}\text { Length group } \\
(\mathrm{cm})\end{array}$ & $\begin{array}{c}\text { No. of host } \\
\text { examined }\end{array}$ & $\begin{array}{c}\text { No. of host } \\
\text { infected }\end{array}$ & $\begin{array}{c}\text { No. of } \\
\text { parasites }\end{array}$ & $\begin{array}{c}\text { Prevalence \% } \\
\text { pean intensity } \\
\text { ratio }\end{array}$ & $\begin{array}{c}\text { Abundance } \\
\text { ratio }\end{array}$ \\
\hline Less than 10 & 50 & 15 & 64 & 30.0 & 4.26 & 1.28 \\
$10-12$ & 70 & 35 & 94 & 50.0 & 2.68 & 1.34 \\
$12-14$ & 65 & 24 & 69 & 36.9 & 2.87 & 1.06 \\
$14-16$ & 35 & 9 & 31 & 25.7 & 3.44 & 0.88 \\
Above 16 & 30 & 6 & 15 & 20.0 & 3.50 & 0.50 \\
\hline Total & 250 & 89 & 273 & 35.6 & 3.06 & 1.09 \\
\hline
\end{tabular}


Table 3. Comparative prevalence \%, mean intensity and abundance of C. complanatum in male and female C. punctatus.

\begin{tabular}{lcccccc}
\hline Fish & $\begin{array}{c}\text { No. of host } \\
\text { examined }\end{array}$ & $\begin{array}{c}\text { No. of host } \\
\text { infected }\end{array}$ & No. of parasites & $\begin{array}{c}\text { Prevalence } \\
\%\end{array}$ & $\begin{array}{c}\text { M ean intensity } \\
\text { ratio }\end{array}$ & $\begin{array}{c}\text { Abundance } \\
\text { ratio }\end{array}$ \\
\hline Male & 126 & 42 & 109 & 33.3 & 2.59 & 0.86 \\
Female & 124 & 47 & 164 & 37.9 & 3.48 & 1.32 \\
\hline
\end{tabular}

In Aphanius sophiae prevalence of infection in male and female were observed to be 53.5 and 32.9 , respectively (Hosseini, 1987). In C. punctatus prevalence was found to be 50 among females and 33 among the male (Firdaus, 1988) and in A phanius dispar $47.5 \%$ male and $55.9 \%$ female fish were infected (Kalantam et al., 1987). The result of present study showed there is no significant difference in susceptibility of infection between male and female.

It was concluded that the prevalence of parasites significantly decrease with increase in length and no significant difference was observed in relation to abundance. Decrease in the prevalence of infection in the larger fish could be due to increase in the mortality of infected fish, increase in the built up of humoral and non specific immunity against the parasites. As the small size fishes survive the infection, they grow to occupy new niches and acquire better microhabitat against parasitic infestation. In winter season metacercarial burden was maximum due to reduced immune response of fishes because of fall in water temperature.Keeping in view of the significance of the pathogenecity of the infection further research on the ecology and epidemiology of the larval forms is needed to understand the major risks threatening the fish industry.

\section{ACKNOWLEDGEMENTS}

We are thankful to Head of Zoology Department (D.N.P.G. College, Meerut) for providing laboratory facilities. We are also thankful to Dr. H.S. Singh, Head Department of Zoology, C.C.S. University Meerut for his Co-operation and U.G.C. for providing financial support.

\section{REFERENCES}

Akhter M., D’Silva, J. and Khatun, A. (1997). Helminth Parasites of Anabas testudineus (Bloch) in Bangladesh. Bangladesh J Zool., 25:135-138.

Aohagi Y. and Shibahara T. (1994). Clinostomum complanatum infection in Carassius spp. collected from some ponds and rivers in Tottori and Shimane Prefecture. Japan. Jpn J Parasitol., 43(2): 129-135.

Aohagi, Y., Shibahara, T. and Kagota K. (1993). Clinostomum complanatum (Trematoda) infection in fresh water fish from fish dealers in Tottori. J ap. J. Vet. M ed. Sci., 55(1): 153-4.

Aohagi, Y., Shibahara T. and Kagota, K. (1992 a). Clinostomum complanatum (Trematoda: Clinostomatidae) in five new fish host in Japan. J. Wildl. D is., 28: 467-469.

Banu, A.N.H., Hossain, M.A. and Khan M.H. (1993). Investigation into the occurrence of parasites in carps, catfish and tilapia. Progr. Agricult., 4:11-16.

Chung D.I., Moon C.H., Kong H.H., Choi D.W., Lim D.K. (1995). The first human case of Clinostomum complanatum
(Trematoda: Clinostomatidae) infection in Korea. Korean J. P arasitol., 33(3):219-223.

Eiras, J.C. (1994). Elementos de Ictioparasitologia. Fundacao Eng. Antoniode Almeida, Porto.

Firdaus, S. (1988). Seasonal incidence of helminth infection in relation to sex of host, Channa punctatus (Bloch). Rivista di parasitol., $3(47,2):$ 215-20.

Golder, M.I., Chandra, K.J. and Rahman, A.K.A. (1987). Helminth parasitism in Nandus nandus (Hamilton). Bangladesh J. Fish., 10: 11-12.

Hosseini, S.H. (1987). The study of infection of fish with Clinostomum sp. in the lake of south of Tehran. Dissertation for veterinary medicine. University of Tehran (In Persian).

Hunter, G. W. and Hunter,W. S. (1934). The life cycle of the yellow grub of fish. J ournal of Parasitology, 20:325.

Isobe, A., Kinoshita, S., Hojo, N., Fukushima, T., Shiwaku, K. and Yamaney (1994). The 12th human case of C linostomum sp. Infection in Japan. J ap. J . Parasitol., 43(3): 193-8.

Kagei, N., Yanohara, Y., Uchikawa, R. and Sato, S. (1984). On the yellow grubs, metacercariae of Clinostomum complanatum (Rudolphi, 1819) found in the cultured loach. J pn. J. Parasit., 33(1): 59-62.

Kagei, N., Yanohara Y., Uchikawa R. and Sato S. (1988). Natural infection with Clinostomum complanatum (Rud., 1819) in the bird of southern Japan. J pn. J. Parasitol., 37 (4): 254257.

Kalantam, A.M.N., Arfin, M. and Nizami W.A. (1987). Seasonal incidence and pathogenicity of the metacercariae of Clinostomum complanatum in Aphanius dispar. J pn J. Parasitol., 36(11): 17-23.

Kifune, T., Ogata, M. and Miyahara, M. (2000). The first case of human infection with Clinostomum (Trematoda: Clinostomidae) in Yamaguchi Prefecture, Japan. Med Bull Fukuoka U niv., 27: 101-105.

Lo, C. F., Huber,F., Kou, G. H. and Lo, C. J. (1981). Studies of Clinostomum complanatum (Rud., 1819). Fish Pathology, 15:219-227.

Lo, C.F., Kou, G. H., Huber, F. and Liu F.G. (1987). The study of Clinostomum complanatum (Rudolphi, 1819).1. The metacercaria of Clinostomum complanatum in the sweet fish (Plecoglassus altivelis). The memoir of Parasitology in fish disease, 2(1): 56-63.

Long-Qi, X., Sen-Hai, Y. and Ying-Dan C. (2004). Clonorchis sinensis in China. In Food-borne helminthiasis in Asia. Asian Parasitology Federation of Asian Parasitologists, 1:1-26.

Malek, M. and Mobedi, I. (2001). Occurrence of C linostomum complanatum (Rudolphi, 1819) (Digenea: Clinostomatidae) in Capoeta capoeta gracilis (Osteichthys: Cyprinidae) from Shroud River, Iran. Iranian J ournal of Public Health, 4: 95 $-98$.

Margolis, L., Esch, G.W., Holmes, J.C., Kuris, A.M. and Schad G.A. (1982). The use of ecological terms in parasitology (Report of an Ad Hoe Committee of the American Society of Parasitologist). J. Parasitol., 68 (1): 131-133. 
Mitchell, A.J. (1995). Yellow grub and other problems associated with aquatic birds. Aquacult. M ag. 21, 93-97.

Sithithaworn, P. and Haswell-Elkins M. (2003). Epidemiology of O pisthorchis viverrini. Acta Trop., 88:187-194.
Yamaguti (1958). Systema helminthum Part 1. The digenetic trematodes of vertebrates. Interscience Publication, N.Y, $214 \mathrm{pp}$. 